\title{
PERILAKU MEKANIS BETON MUTU TINGGI DENGAN VARIASI PENGGUNAAN SUPERPLASTICIZER
}

\author{
Teguh Arifmawan Sudhiarta ${ }^{1}$, I M. Alit K. Salain ${ }^{2}$, I N. Sutarja ${ }^{3}$
}

\begin{abstract}
Abstrak : Beton sendiri cukup popular dalam hal penggunaan di bidang konstruksi (jembatan, bangunan, dan bendungan). Pada proyek yang besar dan berkondisi khusus (ekstrim) seperti pembangunan jembatan dengan bentang panjang di tengah laut, pembangunan dermaga, bangunan tinggi dan dinding penahan ombak laut perlu menggunakan beton mutu tinggi. Untuk bisa membuat beton mutu tinggi diperlukan nilai fas (faktor air semen) yang rendah yaitu berkisar antara 0,20 - 0,30 (ACI, 1998). Pada pengerjaan beton mutu tinggi di lapangan, untuk memudahkan pengerjaan beton karena mengingat menggunakan air yang sedikit, maka diperlukan bahan admixture berupa Superplasticizer untuk memudahkan pengadukan beton.

Penelitian ini dilaksanakan dengan tujuan untuk mengetahui kinerja dari masing-masing superplasticizer ditinjaui dari nilai slump, kuat tekan beton, dan kuat tarik belah beton. Perhitungan kebutuhan bahan mengacu pada SNI 03-6468-2000 dengan perbandingan berat antara semen : agregat halus : agregat kasar sebesar $1,00: 1,67: 2,15$ dengan factor air semen 0,317 . Untuk pengujian digunakan benda uji berbentuk silinder dengan diameter $150 \mathrm{~mm}$ dan tinggi $300 \mathrm{~mm}$ dimana untuk satu umur uji dibuat 3 (tiga) buah benda uji. Pembuatan dan perawatan benda uji dilakukan dengan tata cara standar.

Hasil penelitian menunjukan bahwa penggunaan superplasticizer jenis Napthalene Formaldehyde Sulphonate memberikan hasil kuat tekan yang lebih baik dibandingkan superplasticizer jenis Aqueous Solution Of Modified Polycarboxylate Copolymers yaitu sebesar 7,70\%, namun bila dilihat dari segi kuat tarik dan nilai slump (kelecakan) superplasticizer jenis Aqueous Solution of Modified Polycarboxylate Copolymers memberikan nilai yang lebih baik bila dibandingkan dengan Napthalene Formaldehyde Sulphonate yaitu sebesar 4,04\% untuk kuat tarik belah dan $22,22 \%$ untuk nilai slump.
\end{abstract}

Kata kunci : Beton Mutu Tinggi, Faktor Air Semen, Superplasticizer, Perilaku Mekanis Beton

\section{MECHANICAL BEHAVIOR OF HIGH QUALITY CONCRETE WITH VARIATION OF USE SUPERPLASTICIZER}

\begin{abstract}
Concrete itself is quite popular in terms of usage in the field of construction (bridges, buildings, and dams). In large projects and unconditioned special (extreme) as the long-span bridge construction in the middle of the sea, pier construction, buildings and retaining walls high sea waves need to use high-quality concrete. To be able to make high strength concrete required fas value (water-cement ratio) is low, ranging from 0.20 to 0.30 (ACI, 1998). In high quality concrete workmanship in the field, to facilitate construction of concrete because considering using a little water, then a superplasticizer admixture materials needed to facilitate mixing concrete.

This study was conducted to determine the performance of each in terms of value Slump superplasticizer, concrete compressive strength and split tensile strength of concrete. Calculation of SNI 03-6468-2000 material refers to the weight ratio of cement: fine aggregate: coarse aggregate of 1.00: 1.67: 2.15 with water cement factor of 0.317 . Used to test a cylindrical specimen with a diameter of $150 \mathrm{~mm}$ and height of $300 \mathrm{~mm}$ which for the life of the test was made three (3) pieces of the specimen. Preparation and treatment of test specimens performed by standard procedures.

The results showed that the use of superplasticizer type Napthalene Formaldehyde Sulphonate deliver results better compressive strength than the type superplasticizer Aqueous Solution of Modified Polycarboxylate Copolymers is equal to $7.70 \%$, but when viewed in terms of tensile strength and slump value (kelecakan) type superplasticizer Aqueous Solution Of Modified Polycarboxylate Copolymers provide better value Napthalene Formaldehyde Sulphonate when compared with that of $4.04 \%$ for split tensile strength and $22.22 \%$ for the slump value.
\end{abstract}

Keywords: High Quality Concrete, Cement Water Factor, superplasticizer, Mechanical Behavior of Concrete

\footnotetext{
${ }^{1}$ Mahasiswa Program Studi Magister Teknik Sipil, Program Pascasarjana Universitas Udayana

${ }^{2}$ Staf Pengajar Program Studi Magister Teknik Sipil, Program Pascasarjana Universitas Udayana
} 


\section{PENDAHULUAN}

\subsection{Latar Belakang}

Beton adalah bahan bangunan yang tersusun oleh agregat kasar, agregat halus, semen, dan air. Beton sendiri cukup popular dalam hal penggunaan di bidang konstruksi (jembatan, bangunan, dan bendungan). Pada proyek yang besar dan berkondisi khusus (ekstrim) seperti pembangunan jembatan dengan bentang panjang di tengah laut, pembangunan dermaga, bangunan tinggi dan dinding penahan ombak laut perlu menggunakan beton mutu tinggi. Karena jika menggunakan beton normal akan memerlukan dimensi penampang yang cukup besar serta kurang memiliki sifat ketahanan terhadap serangan agresif dari lingkungan (sulfat dan klorida).

Untuk bisa membuat beton mutu tinggi diperlukan nilai f.a.s (faktor air semen) yang rendah yaitu berkisar antara 0,20 - 0,30 (ACI, 1998), dimana fungsi air pada proses pembuatan beton hanya sebagai pembantu reaksi kimia yang terjadi pada beton. Pada pengerjaan beton mutu tinggi di lapangan, untuk memudahkan pengerjaan beton karena mengingat menggunakan air yang sedikit, maka diperlukan bahan admixture berupa Superplasticizer untuk memudahkan pengadukan beton (Nugraha, 2007)

Di pasaran, khususnya daerah Denpasar - Bali terdapat beberapa jenis admixture beton berupa superplasticizer yang memiliki kelebihan masing-masing produknya. Untuk mengetahui kinerja dari masing-masing superplasticizer tersebut maka dilakukan pengujian kepada masingmasing produk superplasticizer tersebut, dimana pengujian meliputi nilai slump (workability), kuat tekan beton dan kuat tarik belah beton. Pada penelitian ini digunakan superplasticizer jenis Napthalene Formaldehyde Sulphonate (NFS) dan Aqueous Solution Of Modified Polycarboxylate Copolymers (ASOMPC), dengan rencana mutu beton $60 \mathrm{MPa}$ pada umur 28 hari.

\subsection{Tujuan Penelitian}

Penelitian ini dilaksanakan dengan tujuan untuk mengetahui kinerja dari masing-masing superplasticizer ditinjaui dari nilai slump, kuat tekan beton, dan kuat tarik belah beton.

\section{TINJAUAN PUSTAKA}

Beton mutu tinggi menurut American Concrete Institute (ACI, 1998) merupakan beton yang memiliki kuat tekan diatas $41 \mathrm{MPa}$, serta dalam pembuatan beton mutu tinggi diperlukan adanya kontrol kualitas yang ketat. Beton mutu tinggi mempunyai kemampuan untuk mengembangkan kekuatan dengan cepat cepat melalui perawatan normal. Tercatat hanya dalam waktu 24 jam dapat dikembangkan kuat tekan hingga 21-28 $\mathrm{MPa}$.

Beton mutu tinggi biasanya dibuat dengan faktor air semen (f.a.s) lebih rendah daripada beton normal sehingga menyebabkan kelecakan menjadi rendah, untuk meningkatkan kelecakan usaha yang dapat dilakukan adalah dengan menambahkan superplasticizer (Shivappa, 1998).

Untuk menghasilkan beton yang baik, maka diperlukan perawatan (curing) dengan benar. Tiga aspek penting yang harus diperhatikan dalam perawatan beton adalah metode, lama (durasi), dan temperatur perawatan (Prabir, 1999). Pada beton mutu tinggi perawatan dibagi menjadi dua tahap yaitu initial curing dan wet curing. Initial curing dimulai segera setelah beton segar dicetak, dan wet curing dilakukan sesudah final setting (Wang et al, 1997).

\section{BAHAN DAN METODE PENELITIAN}

\subsection{Bahan}

Pada penelitian ini menggunakan bahan-bahan campuran beton yang terdiri dari air, semen, silicafume, agregat kasar, agregat halus dan superplasticizer. Ketentuan dari masing-masing bahan tersebut dapat diuraikan sebagai berikut.

Agregat halus digunakan pasir alami yang berasal dari benoa, dimana susunan butirnya dirancang memenuhi gradasi zone 2 menurut British Standard (BS-812,1976). Agregat kasar berupa batu pecah dengan ketentuan susunan butirnya dirancang memenuhi gradasi untuk ukuran butiran maksimum 12,5 mm sesuai British Standard (BS-812,1976). 


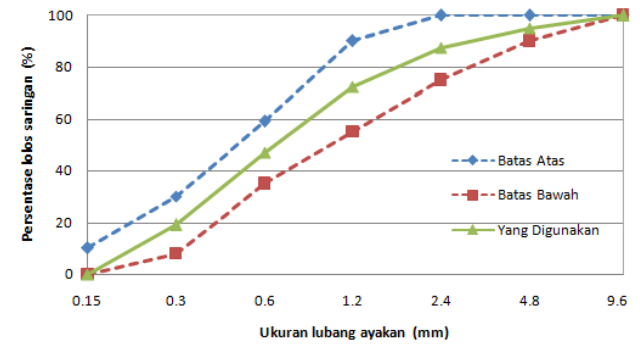

Gambar 1. Rancangan Gradasi Pasir Zone 2 Sumber: British Standar (BS-812,1976)

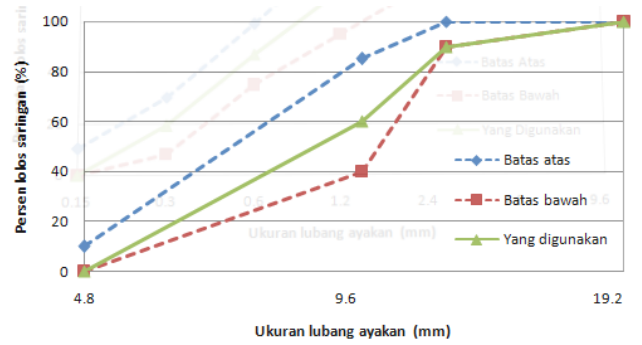

Gambar 2. Rancangan Gradasi Batu Pecah Sumber: British Standar (BS-812,1976)

Air yang digunakan untuk mencampur beton diambil dari saluran PDAM yang ada di Laboratorium Teknologi Bahan, Jurusan Teknik Sipil Fakultas Teknik Universitas Udayana. Untuk perekat hidrolik digunakan semen Portland tipe I. Sedangkan untuk bahan tambah digunakan silica fume sebanyak 5\% dari berat semen dan superplasticizer sebanyak $0,6 \%$ dari berat semen.

Dibuat 2 (dua) macam beton dengan 2 buah superplaticizer yang berbeda yaitu NFS dan ASOMPC, Perbandingan dalam satuan berat antara semen : agregat halus : agregat kasar sebesar 1,00 : 1,67: 2,15 dengan factor air semen 0,317. Kebutuhan bahan ini diperoleh dari perhitungan berdasarkan SNI 03-6468-2000.

\subsection{Metode Penelitian}

Penelitian ini dibagi dalam beberapa tahap yaitu persiapan, pembuatan benda uji, perawatan benda uji, pengumpulan data, dan analisis data. Tahapan persiapan meliputi persiapan alat, pemeriksaan bahan termasuk pembuatan jadwal pelaksanaan. Peralatan yang digunakan seperti alat pencampur, cetakan silinder $300 \mathrm{~mm}$ x $150 \mathrm{~mm}$, mesin penggetar, tempat perawatan dan alat uji tekan, uji tarik diperiksa kelayakan kondisi melaksanakan penelitian.

Pemeriksaan bahan menyangkut pemeriksaan karakteristik dari bahan dasar yang digunakan dalam penelitian seperti antara lain berat jenis, berat satuan, rancangan gradasi agregat halus dan agregat kasar yang akan dipergunakan dalam setiap campuran dan lain-lainnya

Pencampuran bahan dilakukan dengan mesin pencampur Mixer dengan mengikuti tata cara yang standar. Jumlah benda uji yang disiapkan disesuaikan dengan umur uji serta jumlah benda uji per pengujian.

Pengukuran kekuatan dilaksanakan pada umur 1, 3, 7, 28 dan 90 hari dengan menggunakan masing-masing 6 (enam) buah silinder $30 \mathrm{~mm}$ x $150 \mathrm{~mm}$ untuk setiap umur uji. Dengan demikian benda uji yang diperlukan untuk masing-masing perlakuan adalah 30 (tiga puluh) buah, sehingga total silinder $300 \mathrm{~mm} \times 150 \mathrm{~mm}$ yang dibuat secara keseluruhan adalah 60 (enam puluh) buah.

Benda uji yang telah dicetak dibiarkan dalam cetakannya selama 24 jam dan setelah itu dibuka dari cetakannya untuk selanjutnya mendapatkan perawatan. Perawatan dilaksanakan dengan cara menutupi beton dengan karung goni basah. Lalu dilakukan penyiraman dengan tujuan menjaga keadaan beton tetap lembab sampai dengan waktu yang ditentukan untuk pengujian 1, 3, 7, 28, dan 90 hari.

Pengujian dilakukan di

Laboratorium Teknologi Bahan Jurusan Teknik Sipil Fakultas Teknik Universitas Udayana. Data yang dikumpulkan berupa nilai slump, beban hancur untuk kuat tekan, dan beban hancur untuk kuat tarik belah Semuanya itu diperoleh dari hasil pengujian dari benda uji silinder sesuai dengan umur uji yang ditetapkan. Sebelum pengujian benda uji ditimbang.

Untuk keperluan menarik kesimpulan dilakukan pembahasan yang melibatkan parameter yang diuji maupun teori-teori terkait yang ada di dalam literatur. Untuk memudahkan pemahaman terhadap pembahasan, hasil uji akan ditampilkan dalam bentuk tabel-tabel maupun kurvakurva.

\section{HASIL DAN PEMBAHASAN}

\subsection{Karakteristik Bahan}

\# Air

Dalam penelitian ini air yang digunakan untuk mencampur beton adalah air PDAM yang ada di laboratorium Teknologi Bahan. 
Tidak dilakukan pemeriksaan terhadap air tersebut dengan asumsi telah layak digunakan untuk mencampur beton.

\section{* Semen}

Semen yang digunakan semen type I merk Gresik yang didapatkan dari Torsina Redikon Ready Mix Nusa Dua - Bali. Pemeriksaan terhadap semen meliputi penentuan berat volume, dan dari pemeriksaan didapatkan bahwa berat volume semen adalah $1,334 \mathrm{gr} / \mathrm{cm}^{3}$

\section{* Agregat}

Pemeriksaan terhadap kadar lumpur, berat satuan, berat jenis Kering oven dan penyerapan dari agregat halus dan agregat kasar memberikan hasil seperti ditampilkan pada Tabel 1. Pada tabel tersebut juga ditampilkan hasil daya tahan agregat kasar terhadap pembubukan yang dilakukan dengan alat uji Los Angeles

Tabel 1. Karakteristik Agregat Halus dan Agregat Kasar

\begin{tabular}{|l|c|c|}
\hline \multicolumn{1}{|c|}{ Parameter } & $\begin{array}{c}\text { Agregat } \\
\text { Halus }\end{array}$ & $\begin{array}{c}\text { Agregat } \\
\text { Kasar }\end{array}$ \\
\hline Kadar Lumpur (\%) & 2,80 & 0,40 \\
\hline Berat satuan (gr/cm ${ }^{3}$ ) & 1,73 & 1,39 \\
\hline $\begin{array}{l}\text { Berat Jenis Kering } \\
\text { oven }\end{array}$ & 2,39 & 2,41 \\
\hline Penyerapan (\%) & 1,22 & 2,14 \\
\hline $\begin{array}{l}\text { Keausan dengan Los } \\
\text { Angeles (\%) }\end{array}$ & - & 26,09 \\
\hline
\end{tabular}

Sumber: Pengujian, 2014

\subsection{Nilai Slump (workability)}

Pengujian nilai slump untuk setiap perlakuan dari superplasticizer dapat dilihat pada Tabel 2.

Tabel 2. Hubungan Jenis Superplasticizer dengan Kelecakan beton Segar.

\begin{tabular}{|l|l|c|}
\hline No & $\begin{array}{c}\text { Jenis } \\
\text { Superplasticizer }\end{array}$ & Slump $(\mathrm{mm})$ \\
\hline 1 & NFS & 72 \\
\hline 2 & ASOMPC & 88 \\
\hline
\end{tabular}

Sumber: Pengujian, 2014

Dari Tabel 2 dapat dilihat bahwa penggunaan superplasticizer jenis NFS memberikan nilai slump yang lebih rendah dibandingkan dengan beton yang menggunakan superplasticizer jenis ASOMPC, dimana hal ini menunjukan bahwa beton yang menggunakan superplasticizer jenis NFS lebih susah dikerjakan daripada beton yang menggunakan ASOMPC.

\subsection{Kuat Tekan Beton}

Hasil pengujian kuat tekan beton untuk setiap perlakuan dari superplasticizer untuk setiap umur uji ditampilkan pada Gambar 3.

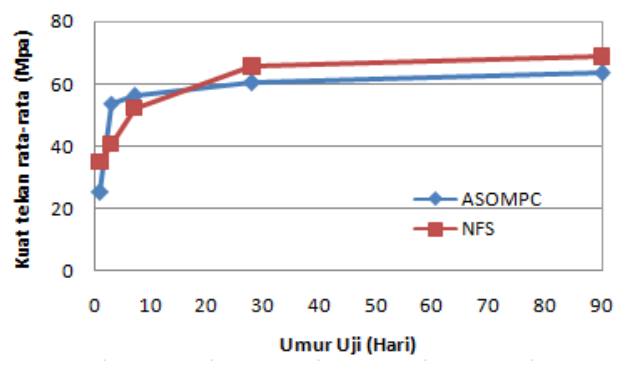

Gambar 3. Hubungan Kuat Tekan Beton

Dengan Variasi Superplasticizer

Sumber: Analisis, 2014

Dari Gambar 3. Dapat dilihat bahwa beton dengan menggunakan superplasticizer jenis NFS memiliki kecenderungan perkembangan kekuatan yang lebih lambat dibandingkan beton dengan superplasticizer jenis ASOMPC pada umur awal. Seiring dengan bertambahnya umur yaitu pada umur 28 dan 90 hari terlihat bahwa beton dengan superplasticizer jenis NFS memiliki kecenderungan perkembangan kekuatan lebih tinggi bila dibandingkan dengan beton dengan superplasticizer jenis ASOMPC.

\subsection{Kuat Tarik Belah Beton}

Hasil pengujian kuat tarik belah beton untuk setiap perlakuan dari superplasticizer untuk setiap umur uji dapat dilihat pada Gambar 4.

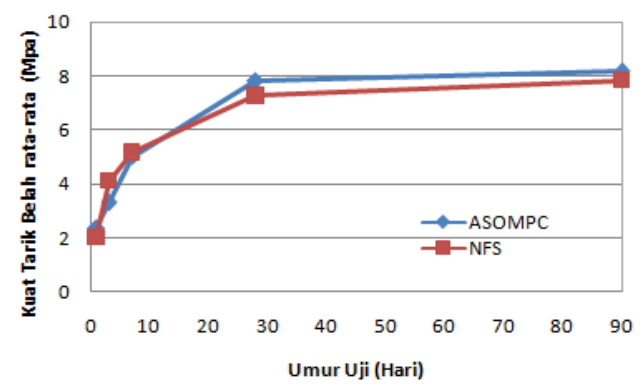

Gambar 4. Hubungan Kuat Tarik Belah

Beton Dengan Variasi Superplasticizer Sumber: Analisis, 2014

Dari Gambar 4. Dapat dilihat bahwa beton dengan menggunakan superplasticizer jenis NFS memiliki kecenderungan perkembangan kekuatan yang lebih tinggi dibandingkan beton yang menggunakan superplasticizer jenis ASOMPC pada umur 
awal. Seiring dengan bertambahnya umur yaitu pada umur 28 dan 90 hari terlihat bahwa beton dengan superplasticizer jenis NFS memiliki kecenderungan perkembangan kekuatan lebih rendah bila dibandingkan dengan beton dengan superplasticizer jenis ASOMPC.

\subsection{Pembahasan}

Terlihat bahwa beton dengan penggunaan superplasticizer jenis NFS menyebabkan nilai slump yang cukup rendah bila dibandingkan dengan beton yang menggunakan superplasticizer jenis ASOMPC, hal ini dapat disebabkan oleh karakteristik NFS yang memiliki kemampuan mempercepat pengeringan beton (PT. Sika Indonesia, 2014) sehingga dengan dengan waktu cetak yang sama dengan beton yang menggunakan ASOMPC akan mengakibatkan beton (dengan ASOMPC) lebih mudah diaduk.

Pengaruh jenis superplasticizer pada perkembangan kuat tekan beton dapat dilihat bahwa beton dengan NFS memiliki kuat tekan yang lebih baik dari ASOMPC, hal ini dapat disebabkan karna karakteristik dari NFS dapat meningkatkan kuat tekan beton sebanyak $40 \%$ pada umur 28 hari (PT. Sika Indonesia, 2014), tetapi bila diperhatikan lebih seksama perbedaan kuat tekan beton yang menggunakan NFS dan ASOMPC tidak jauh signifikan hanya sebesar 7,70\%.

Pada pengujian kuat tarik belah terlihat bahwa beton dengan superplasticizer jenis ASOMPC memiliki kuat tarik belah yang lebih baik dari NFS, hal ini dapat disebabkan karna karakteristik dari ASOMPC dapat membuat beton lebih kedap udara (PT. Sika Indonesia, 2014), tetapi bila diperhatikan lebih seksama perbedaan kekuatan tarik belah beton yang menggunakan NFS dan ASOMPC tidak jauh signifikan hanya sebesar 4,04\%.

\section{SIMPULAN DAN SARAN}

\subsection{Simpulan}

Berdasarkan hasil penelitian yang telah dilakukan maka simpulan yang dapat diambil adalah sebagai berikut :

1. Penggunaan superplasticizer jenis NFS pada beton mutu tinggi dapat mengakibatkan nilai slump yang cukup rendah bila dibandingkan dengan beton mutu tinggi yang menggunakan superplasticizer jenis ASOMPC.

2. Penggunaan superplasticizer jenis NFS pada beton mutu tinggi dapat memberikan kuat tekan beton yang lebih baik pada umur 28 dan 90 hari bila dibandingkan dengan beton mutu tinggi yang menggunakan superplasticizer jenis ASOMPC.

3. Penggunaan superplasticizer jenis NFS pada beton mutu tinggi dapat memberikan kuat tarik belah yang lebih rendah pada umur 28 dan 90 hari bila dibandingkan dengan beton mutu tinggi yang menggunakan ASOMPC.

\subsection{Saran}

Beberapa hal yang kami jadikan saran yaitu :

1. Penggunaan superplasticizer hendaknya disesuaikan dengan kebutuhan karna mengingat harga dari NFS dan ASOMPC cukup jauh rangenya dan hasil pengujian perilaku mekanis (kuat tekan dan kuat tarik) tidak jauh berbeda yaitu $7,70 \%$ untuk kuat tekan dan $4,04 \%$ untuk kuat tarik belah.

2. Jika menginginkan pembuatan beton mutu tinggi dengan nilai kelecakan yang lebih baik hendaknya menggunakan superplasticizer jenis ASOMPC, karna mengingat jenis NFS memberikan nilai slump yang cukup kecil dan kenyataan di lapangan cukup susah untuk diaduk.

\section{UCAPAN TERIMA KASIH}

Penulis, dalam kesempatan ini, menyampaikan terima kasih kepada semua pihak yang telah memberikan dukungan dan kontribusi di dalam pelaksanaan penelitian ini.

\section{DAFTAR PUSTAKA}

American Concrete Intitute. 1993, Guide For Selecting Proportions For HighStrength Concrete With Portland Cemen And Fly Ash, ACI 211.4R-93, USA.

Badan Standarisasi Nasional. 1990, Metode Pengujian Tekan Beton, SNI 03-19741990, Jakarta. 
Badan Standarisasi Nasional. 2000, Tata Cara Perencanaan Beton Kekuatan Tinggi Dengan Semen Portland Dan Abu Terbang, SNI 03-6468-2000, Jakarta.

Badan Standarisasi Nasional. 2002, Metode Pengujian Kuat Tarik Belah Beton, SNI 03-2491-2002, Jakarta.

Metha, P.K. 1986, Concrete: Structure, Properties And Materials, $1^{\text {st }}$ edition, New York: Prentice Hall Inc.

Mulyono, T. 2004, Teknologi Beton, ANDI, Yogyakarta

Nugraha, P. 2007, Teknologi Beton Dari Material, Pembuatan, Ke Beton Kinerja Tinggi, Universitas Kristen Indonesia, Andi Offset, Yogyakarta.

Prabir, C.B, 1999, Curing High Performance Concrete, International Symposium On Innovative World Of Concrete Vol II, pp 6.25-6.34.

PT. Sika Indonesia. 2014, Katalog Produk Superplasticizer Sika, Jakarta

Salain, I.M.A.K. 2007, Perbandingan Kuat Tekan Dan Permeabilitas Beton Yang Menggunakan Semen Portland Pozolan Dengan Yang Menggunakan Semen Portland Tipe I, Seminar dan Pameran HAKI.

Wang, C. 1997, Curing Of High Strenght Concrete, New Orleans, Louisiana. 